\title{
Challenges to the Reliability of Officially Published Statistics for Extension Work
}

\author{
A. A. Ammani ${ }^{1}$, B. M. Sani ${ }^{1}$ and J. F. Alamu ${ }^{2}$ \\ ${ }^{1}$ National Agricultural Extension and Research Liaison Services \\ Ahmadu Bello University, Zaria. \\ ${ }^{2}$ Department of Agricultural Economics and Rural Sociology \\ Ahmadu Bello University, Zaria. \\ Email:aaammani@yahoo.co.uk \\ Mobile: 08039606608
}

\begin{abstract}
The crucial importance of secondary data for socio-economic analysis cannot be overemphasised. The results of research are only as good as the quality of data used: garbage in, garbage out. This paper questions the reliability of officially published statistics. Aggregate maize production data was collected from the official publications of the Central Bank of Nigeria based on the National Bureau of Statistics, for the period 1972-2007. This form our first set of data: published data. Literature on annual growth rate for maize in developing countries was reviewed, from which it was found that the highest ever recorded annual rate of growth for maize, over a period of 10 years was $4.84 \%$; and $3.83 \%$ for a 40 years period. The sub-Saharan African average (less South Africa) was $1.93 \%$ and $1.04 \%$ for the 10 year and 40-year periods respectively. Based on this, an annual growth rate of $7.5 \%$, about twice the highest rate for developing countries, was assumed for maize in Nigeria from 1972-2007. Taking 1972 as the baseline year, our second set of data was generated: expected data. Descriptive graph and the Student's $t$ Test technique for comparison of means of independent samples was then used to test the postulated hypothesis; the hypothesis was rejected indicating that the maize production figures given in our published statistics differ significantly from the corresponding set of expected figures. The paper concluded that data from officially published statistics differs significantly from expected data based on experience elsewhere. Thus, Nigerian published statistics may not be reliable.
\end{abstract}

Keywords: Reliability, Officially published, Statistics, Nigeria.

\section{Introduction}

The success of any socio-economic analysis, which is what agricultural economics and extension analysis is about, ultimately depends on the availability of appropriate, relevant and reliable data. Sources of secondary data used for agricultural economics and extension analysis in Nigeria include governmental agencies: National Bureau for Statistics (NBS), Central Bank of Nigeria (CBN), National Agricultural Extension and Research Liaison Services (NAERLS) etc.; international agencies: World Bank, IMF, FAO, IFDC etc.; and several NonGovernmental Organizations, NGOs. Each of these agencies collects data for one purpose or the other. Most of the data is ultimately published and thus, made available for economics and extension research.

From the foregoing, the crucial importance of secondary data for socioeconomic research and analysis cannot be over-emphasized. Suffice it to say that the results of research are only as good as the quality of data used: garbage in 
garbage out. An aspect of development in Nigeria since independence is the absence of hard facts (Stolper, 1966). Data are difficult to obtain because of poor record keeping (Ogunfowora, 1993). In most cases, where the data were obtainable, their accuracy is doubtful (Morgan, 2008). Consequently, data collection efforts, and the data itself, are clouded with uncertainty.

This paper set out to question the reliability of officially published statistics in Nigeria. If the paper succeeds only in creating doubts in the minds of the readers on the reliability of indices of growth published in Nigeria, it will have achieved its purpose, as its significance lies in initiating debate on the reliability of such data and its implications on agricultural economics and extension practices in Nigeria.

\section{Definition of Terms}

For the purpose of this paper, the following terms are operationally defined as follows:

Published data: Collected time-series data on maize production in Nigeria (19722007) as published by Central Bank of Nigeria (CBN, 2007).

Expected data: Data maize production in Nigeria (1972-2007) generated for the purpose of this study, based on an assumed annual growth rate of $7.5 \%$, by adding $7.5 \%$ of the previous year's figure to the present with 1972 taken as base year.

Reliability: Reliability of published data in Nigeria refers to the degree to which the published data statistically conforms to the expected data. Mathematically, Published data $\leq$ expected data.

\section{Methodology}

Secondary data on annual aggregate maize crop production in Nigeria was collected from the official publications of the Central Bank of Nigeria based on the National Bureau of Statistics for the years 1972-2007. This form our first set of data: published data. Literature on annual growth rate for maize in developing countries was reviewed, from which the highest ever recorded annual rate of growth for maize, over a period of 10 and 40 year period was found, and based on it an annual growth rate for maize in Nigeria was assumed for the period 1972-2007, and used to generate our second set of data: expected data. A graphical comparison of the 2 sets of data was prepared; and the Student's $t$ test technique for comparison of means of independent samples was then used to statistically compare the 2 sets of data, at the $5 \%$ level of significance. For a description of the Student's $t$ test technique see Hogg and Craig (1995); Lehmann (1991); and Keller and Warrack (2003).

\section{Findings}

Secondary data, our published data, on annual aggregate maize crop production in Nigeria was collected from the joint official publications of the Central Bank of Nigeria based on the National Bureau of Statistics for the years 1972-2007. Literature on annual growth rate for maize in developing countries was reviewed, from which it was found that the highest ever recorded annual rate of growth for maize, over a period of at least 10 years, was $4.84 \%$; and $3.83 \%$ for a 40 years period. The subSaharan African average (less South Africa) was $1.93 \%$ and $1.04 \%$ for the 10 -year and 40-year period respectively (Table 1). Based on this, a generous annual growth rate of $7.5 \%$, about twice the highest rate for developing countries, was assumed for maize in Nigeria from 1972-2007. Our second set of data, expected data, was 
generated by adding $7.5 \%$ of the previous year's figure to the present with 1972 taken as base year.

Table 1: Annual Rate of Growth on Yield for Maize in Developing Countries

\begin{tabular}{llllll} 
Region/Country & $\begin{array}{l}1956- \\
1995\end{array}$ & $\begin{array}{l}1956- \\
1965\end{array}$ & $\begin{array}{l}1966- \\
1975\end{array}$ & $\begin{array}{l}1976- \\
1985\end{array}$ & $\begin{array}{l}1986- \\
(\%)\end{array}$ \\
& $(\%)$ & $(\%)$ & $(\%)$ & $(\%)$ \\
\hline $\begin{array}{l}\text { South, East, and South-East } \\
\text { Asia, less China }\end{array}$ & 1.70 & 1.23 & 1.43 & 2.96 & 2.26 \\
West Asia and North Africa & 2.75 & 3.74 & 1.85 & 2.52 & 2.28 \\
$\begin{array}{l}\text { Sub-Saharan Africa less } \\
\text { South Africa }\end{array}$ & 1.04 & 0.41 & 1.93 & -0.26 & 0.17 \\
China & & & & & \\
Brazil & 3.83 & 0.09 & 4.10 & 4.84 & 3.30 \\
Argentina & 1.68 & 0.68 & 1.47 & 2.62 & 4.29 \\
South Africa & 2.61 & 0.29 & 2.43 & 2.29 & 3.58 \\
Source: Pingali and Heisey (1999). & 1.81 & 1.08 & 4.67 & -3.46 & -2.27
\end{tabular}

Table 2: Published and Expected Maize Production Data in Nigeria.

\begin{tabular}{|c|c|c|c|c|c|}
\hline Year & $\begin{array}{c}\text { Maize } \\
\text { Output } \\
\text { Published } \\
\text { ('000 MT) }{ }^{a}\end{array}$ & $\begin{array}{l}\text { Maize Output } \\
\text { Expected } \\
\text { ('000 MT) }\end{array}$ & Year & $\begin{array}{c}\text { Maize } \\
\text { Output } \\
\text { Published } \\
\text { ('000 MT) }{ }^{\mathrm{a}}\end{array}$ & $\begin{array}{c}\text { Maize } \\
\text { Output } \\
\text { Expected } \\
\text { ('000 MT) }\end{array}$ \\
\hline 1972 & 639 & 639 & 1990 & 5768 & 2525.02 \\
\hline 1973 & 808 & 738.45 & 1991 & 5810 & 2714.4 \\
\hline 1974 & 528 & 793.83 & 1992 & 5840 & 2917.98 \\
\hline 1975 & 1332 & 853.37 & 1993 & 6290 & 3136.82 \\
\hline 1976 & 1068 & 917.37 & 1994 & 6902 & 3372.09 \\
\hline 1977 & 650 & 986.18 & 1995 & 6931 & 3624.99 \\
\hline 1978 & 658 & 1060.14 & 1996 & 6217 & 3896.87 \\
\hline 1979 & 488 & 1139.65 & 1997 & 6285 & 4189.13 \\
\hline 1980 & 612 & 1225.12 & 1998 & 6435 & 4503.32 \\
\hline 1981 & 720 & 1317.01 & 1999 & 6515 & 4841.07 \\
\hline 1982 & 766 & 1415.78 & 2000 & 6491 & 5204.15 \\
\hline 1983 & 594 & 1521.97 & 2001 & 8188.5 & 5594.46 \\
\hline 1984 & 2058 & 1636.12 & 2002 & 8527.9 & 6014.04 \\
\hline 1985 & 1190 & 1758.82 & 2003 & 8685.1 & 6465.09 \\
\hline 1986 & 1336 & 1890.74 & 2004 & 9503.4 & 6949.98 \\
\hline 1987 & 4612 & 2032.54 & 2005 & 10369.6 & 7471.22 \\
\hline 1988 & 5268 & 2184.98 & 2006 & 11087.4 & 8031.57 \\
\hline 1989 & 5008 & 2348.86 & 2007 & 11520 & 8633.93 \\
\hline
\end{tabular}

Source: ${ }^{a} C B N$ (2007). ${ }^{b}$ Estimated by adding $7.5 \%$ of the previous year's figure to the present with 1972 taken as base year. 
Figure 1 below, gives a graphic representation of how the 2 sets of data employed in this study, as contained in Table 2, compare over the period 1972-2007. It appears that the 2 sets of data are different. To ascertain whether the 2 sets of data are statistically significantly different we go on to test our hypothesis.

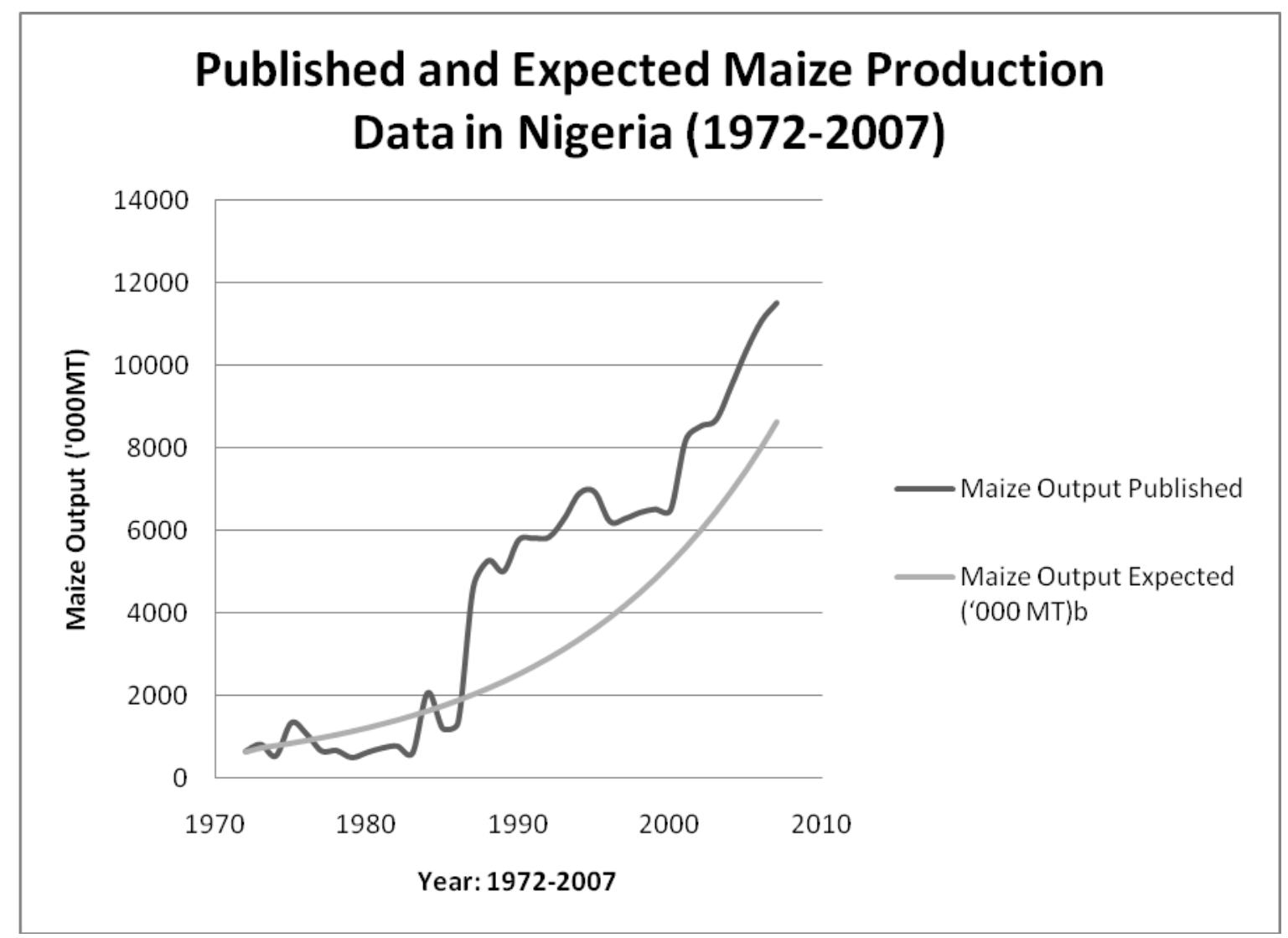

Fig. 1: Published data and Expected data (1972-2007) compared.

The hypothesis formulated and tested in this study is that there is no significant difference between published data and expected data. From the results of the Student's $t$ test, the calculated $t$ value of 2.024 is found to be significant when viewed in relation to the computed $p$-value of 0.047 , hence the null hypothesis is rejected and it is thus concluded that there is a significant difference between maize growth indices published in Nigeria and the expected data. The mean difference of 1420.9678 indicates that the officially published maize statistics is greater than the expected data with a mean of 1421 MT.

Table 3: Results of the Student's $t$ test.

\begin{tabular}{ll} 
Parameter & Value \\
\hline N & 72 \\
DF & 70 \\
T value & $2.024^{\mathrm{a}}$ \\
Mean Difference & 1420.9678 \\
Standard Error Difference & 702.16219 \\
$a=(p<0.05)$ &
\end{tabular}




\section{Conclusion}

The crucial importance of secondary data for socio-economic research and analysis cannot be over-emphasized. This paper questions the reliability of published statistics in Nigeria. It argued that indices of agricultural growth published in Nigeria, taken maize production as an instance, are statistically significantly higher than almost twice that reported in other developing nations of the world: thus, Nigerian published statistics may not be reliable. The paper recognizes its limitations in that it only made observations which are not substantiated by primary research, thus, the observations of the paper are suggestive and not conclusive.

\section{Reference}

CBN (2007). Central Bank of Nigeria Statistical Bulletin Volume 18. Abuja: Central Bank of Nigeria.

Hogg, R. V. and A. T. Craig (1995). Introduction to Mathematical Statistics, $5^{\text {th }}$ edition. Englewood Cliffs, NJ: Prentice Hall.

Keller, G. and Warrack, B. (2003) Statistics for Management and Economics, $6^{\text {th }}$ edition. Pacific Grove, CA: Thomson Brooks/Cole.

Lehmann, E. L. (1991). Testing Statistical Hypotheses, $2^{\text {nd }}$ edition. New York: Chapman \& Hall.

Morgan, M. S. (2008). "On a Mission" with Mutable Mobiles. Working Papers on the Nature of Evidence: How Well Do 'Facts' Travel? No. 34/08. London: London School of Economics.

Ogunfowora, O. (1993). Analysis of Fertilizer Supply and Demand in Nigeria. In Mijindadi, N. B., Philip, D. O. A. and Jayaraman, P. (Eds). Alternative Pricing and Distribution System for Fertilizer in Nigeria. Ibadan: FACU.

Pingali, P.L., and P.W. Heisey (1999). Cereal Crop Productivity in Developing Countries. CIMMYT Economics Paper 99-03. Mexico D.F.: CIMMYT.

Stolper, W. F. (1966) Planning Without Facts: Lessons in Resource Allocation from Nigeria's Development. Cambridge, Mass: Harvard University Press. 